\title{
Evaluation of Yard Long Bean (Vinna unguiculata subsp. sesquipedalis) Genotypes for Collar Rot and Web Blight
}

\author{
V.Sivakumar $^{1^{*}}$, V.A. Celine ${ }^{1}$ and V.K. Girija ${ }^{2}$ \\ ${ }^{1}$ Department of Olericulture, Kerala Agricultural University, Vellayani, \\ Trivandrum-695522, India \\ ${ }^{2}$ Department of Plant Pathology, Kerala Agricultural University, Vellayani, \\ Trivandrum, India \\ *Corresponding author
}

\section{A B S T R A C T}

\begin{tabular}{l} 
K e y w or d s \\
$\begin{array}{l}\text { Collar rot, } \\
\text { Rhizoctonia solani, } \\
\text { Web blight, } \\
\text { Yard long bean }\end{array}$ \\
Article Info \\
$\begin{array}{l}\text { Accepted: } \\
\text { 28 January } 2018 \\
\text { Available Online: } \\
\text { 10 July } 2018\end{array}$ \\
\hline
\end{tabular}

Forty four accessions of yard long bean were screened for resistance against collar rot and web blight caused by Rhizoctonia solani at College of Agriculture, Vellayani, Thiruvananthapuram. Evaluations were conducted in vivo and in vitro for disease reaction. Among 44 accessions screened under field conditions, fourteen accessions exhibited collar rot symptoms at seedling stage, the rest of the accessions were free from collar rot under field conditions. There was no incidence of web blight throughout growing period. To confirm resistance, evaluation was conducted under artificial epiphytotic conditions. Based on disease severity, accessions were categorized in to five groups $\mathrm{Viz}$., resistant, tolerant, moderately tolerant, susceptible, and highly susceptible. Twelve accessions showed resistant reaction; four accessions were tolerant; ten accessions moderately tolerant; five were susceptible and thirteen accessions highly susceptible to collar rot and web blight.

\section{Introduction}

The genus Vigna contains several important cultivated legume species including yard long bean (Vigna unguiculata ssp. sesquipedalis), cowpea (V. unguiculata ssp. unguiculata), mungbean $(V$. radiata), blackgram $(V$. mungo), bambara groundnut (V. subterranea), moth bean ( $V$. aconitifolia), adzuki bean $(V$. angularis) and rice bean ( $V$. umbellata).
Among these, yardlong bean, also known as asparagus bean, sitao, bodi bean, and snake bean, is widely cultivated in Southeast Asia (Fery, 2002). It is claimed to be one of the most important vegetable crops in China, Indonesia, Philippines, Taiwan, and Thailand (Rachie, 1985). Now-a-days it is being popularized in parts of India as well.

Yard long bean (Vigna unguiculata subsp. 
sesquipedalis Verdc.) is one of the most popular and cosmopolitan vegetable crops. It is a rich and inexpensive source of vegetable protein. It enriches soil fertility by fixing atmospheric nitrogen. Because of its quick growth habit it has become an essential component of sustainable agriculture in marginal lands of the tropics. The crop is adaptable to harsh environments and withstands extreme temperatures, water limiting conditions and poor soil fertility. It yields well in harsh environments where other food legumes do not thrive. Due to adaptation versatility, ability to fix atmospheric nitrogen and considerable level of seed protein, minerals and vitamin contents yard long bean could significantly contribute as viable and alternative crop in low input farming systems.

The production and productivity of yard long bean is mainly constrained by low yield and stability, sensitive to adverse climatic conditions and susceptibility to diseases and insect pests. (Sarutayophat et al., 2007). Incidence of pests and diseases is considered to be a major limiting factor affecting the production and productivity of yard long bean. The growing demand for the yard long bean has led to large scale intensive cultivation. This in turn, resulted in enhanced incidence of pests and diseases inflicting heavy crop loss. Among the diseases, collar rot and web blight caused by Rhizoctonia solani is an important soil borne disease of yard long bean particularly under high temperature and humidity causing severe yield loss. Vigna species (Cowpea, mung bean, yard long bean, etc.) are especially susceptible to seedling diseases caused by $R$. solani when planted in, moist soils coupled with high temperature and humid conditions (Thies et al., 2006).

Collar rot is initially manifested in the collar region of the plants right from the seedling stage. It begins as brownish - black lesions at soil level near collar region girdling the base of the stem resulting in yellowing and drooping of leaves and rotting of roots. White mycelial growth often studded with small sclerotia is characteristically seen on the affected regions. Web blight appears as small circular light greyish-brown spots on leaf lamina which enlarges to oblong or irregular water soaked areas. Later shot hole symptoms are produced or the spots coalesce to cover entire leaf area resulting in shedding of leaves. Collar rot is initially manifested in the collar region of the plants right from the seedling stage. It begins as brownish - black lesions at soil level near collar region girdling the base of the stem resulting in yellowing and drooping of leaves and rotting of roots. White mycelial growth often studded with small sclerotia is characteristically seen on the affected regions. Web blight appears as small circular light greyish-brown spots on leaf lamina which enlarges to oblong or irregular water soaked areas. Later shot hole symptoms are produced or the spots coalesce to cover entire leaf area resulting in shedding of leaves. The collar rot phase of the disease is more severe and wide spread than the web blight phase under field conditions. $R$. solani incidence incurred yield loss of 10-60 per cent in horse gram (Dubey and Mishra, 1990), 30 per cent in urdbean (Sharma, 1999) and 6.66 to 75.35 per cent in mung bean (Gupta and Singh, 2002).

The most economical and environment friendly method of controlling collar rot and web blight in yard long bean appears to be the use of resistant varieties. Breeding for disease resistance is an excellent approach to overcome economic losses caused by pathogen in crop. To initiate breeding for disease resistance, identification of sources of resistance is needed and the development of a technique to screen putative lines is essential. This manuscript reports the results of an experiment planned to identify resistance sources in yard long bean through screening 
under natural as well as artificial conditions with the objective to identify accession which may be used for commercial cultivation in disease prone areas and/or could be utilized in breeding programs.

\section{Materials and Methods}

The study was conducted in two separate experiments. The first experiment was carried out under field conditions at Department of Olericulture, College of Agriculture, Vellayani during 2011-2012 with 44 yard long bean accessions collected from different part of Kerala (Table 1). The trial was laid out in a randomized block design (RBD) with three replications. Seeds were sown at a spacing of $1.5 \mathrm{X} 0.45 \mathrm{~m}$. Since main thrust was given for screening of the accessions for collar rot and web blight under field conditions, fungicide application was avoided to allow natural infection. Ten plants from each accession were randomly selected and scored individually for web blight severity using 0-9 rating scale (Table 2). Disease incidence of collar rot was recorded and Plant disease index (PDI) of web blight was calculated. Ten plants from each accession were randomly selected and scored individually using 0-9 rating scale (Table 2 ).

\section{Table 2: Scale for grading of web blight disease in yard long bean}

\begin{tabular}{|c|l|}
\hline Grade & \multicolumn{1}{|c|}{ Description } \\
\hline $\mathbf{0}$ & No infection \\
\hline $\mathbf{1}$ & $1-10 \%$ of leaf area infected \\
\hline $\mathbf{3}$ & $11-25 \%$ of leaf area infected \\
\hline $\mathbf{5}$ & $26-50 \%$ of leaf area infected \\
\hline $\mathbf{7}$ & $51-75 \%$ of leaf area infected \\
\hline $\mathbf{9}$ & $>75 \%$ of leaf area infected \\
\hline
\end{tabular}

(Mayee and Dattar, 1986)

The second experiment was conducted under net house following artificial inoculation of $R$. solani. All the accessions of yard long bean which were used in field experiment were screened under artificial conditions to confirm the resistance or susceptibility of accessions to collar rot and web blight. This experiment was laid in CRD with three replications.

Table.1 Details of yard long bean accessions used for the study

\begin{tabular}{|c|c|l|l|}
\hline Sl. No. & $\begin{array}{c}\text { Accession } \\
\text { Number }\end{array}$ & \multicolumn{1}{|c|}{ Accession Name } & \multicolumn{1}{|c|}{ Source } \\
\hline $\mathbf{1}$ & VS 1 & Local & College of Horticulture, Vellanikkara \\
\hline $\mathbf{2}$ & VS2 & Local & Payannur, Kannur \\
\hline $\mathbf{3}$ & VS 3 & Local & College of Agriculture, Vellayani \\
\hline $\mathbf{4}$ & VS 4 & Kanjikuzhi Payar & College of Agriculture, Vellayani \\
\hline $\mathbf{5}$ & VS5 & Local & Hosdurg, Kasargode \\
\hline $\mathbf{6}$ & VS 6 & Local & Kumarapuram, Trivandrum \\
\hline $\mathbf{7}$ & VS 7 & Vyjayanthi & College of Horticulture, Vellanikkara \\
\hline $\mathbf{8}$ & VS 8 & Sarika & College of Agriculture, Vellayani \\
\hline $\mathbf{9}$ & VS 9 & Local & Aryanad, Trivandrum \\
\hline $\mathbf{1 0}$ & VS 10 & Local & Kuttipuram, Malapuram \\
\hline $\mathbf{1 1}$ & VS 11 & Lola & College of Horticulture, Vellanikkara \\
\hline $\mathbf{1 2}$ & VS 12 & Malika & College of Agriculture, Vellayani \\
\hline $\mathbf{1 3}$ & VS 13 & Local & Neyyattinkara, Trivandrum \\
\hline $\mathbf{1 4}$ & VS 14 & Local & Sreekaryam, Trivandrum \\
\hline $\mathbf{1 5}$ & VS 15 & Local & Mitraniketan, Vellayani \\
\hline $\mathbf{1 6}$ & VS 16 & Local & Pattom, Trivandrum \\
\hline
\end{tabular}




\begin{tabular}{|l|l|l|l|}
\hline $\mathbf{1 7}$ & VS 18 & Local & Pilicode, Kasargode \\
\hline $\mathbf{1 8}$ & VS 19 & Local & College of Horticulture, Vellanikkara \\
\hline $\mathbf{1 9}$ & VS 20 & Local & College of Horticulture, Vellanikkara \\
\hline $\mathbf{2 0}$ & VS 21 & Local & Thalasserry, Kannur \\
\hline $\mathbf{2 1}$ & VS 22 & IVRCP-1 & College of Horticulture, Vellanikkara \\
\hline $\mathbf{2 2}$ & VS 23 & Local & Vengad, Kannur \\
\hline $\mathbf{2 3}$ & VS 24 & Local & Pattambi, Palakkad \\
\hline $\mathbf{2 4}$ & VS 27 & Local & Aripra, Malapuram \\
\hline $\mathbf{2 5}$ & VS 28 & Local & College of Agriculture, Vellayani \\
\hline $\mathbf{2 6}$ & VS 29 & Local & Aripra, Malapuram \\
\hline $\mathbf{2 7}$ & VS 30 & Local & College of Agriculture, Vellayani \\
\hline $\mathbf{2 8}$ & VS 31 & Local & College of Agriculture, Vellayani \\
\hline $\mathbf{2 9}$ & VS 32 & Local & Kollam \\
\hline $\mathbf{3 0}$ & VS 33 & Local & Haritha Agrofarm, Trivandrum \\
\hline $\mathbf{3 1}$ & VS 34 & Vellayani Local & IF, College of Agriculture, Vellayani \\
\hline $\mathbf{3 2}$ & VS 35 & Local & Periya, Kasargode \\
\hline $\mathbf{3 3}$ & VS 36 & Local & Periya, Kasargode \\
\hline $\mathbf{3 4}$ & VS 37 & Local & Kanjhangad, Kasargode \\
\hline $\mathbf{3 5}$ & VS 38 & Local & Palayam, Trivandrum \\
\hline $\mathbf{3 6}$ & VS 39 & Local & Kanjhangad, Kasargode \\
\hline $\mathbf{3 7}$ & VS 40 & Meter payar & Pilicode, Kasargode \\
\hline $\mathbf{3 8}$ & VS 41 & Local & Pilicode, Kasargode \\
\hline $\mathbf{3 9}$ & VS 42 & Vellayani Jyothika & College of Agriculture, Vellayani \\
\hline $\mathbf{4 0}$ & VS 43 & Local & Ettumanoor, Kottayam \\
\hline $\mathbf{4 1}$ & VS 44 & Local & Kanakkary, Kottayam \\
\hline $\mathbf{4 2}$ & VS 45 & Super Green & Cherthala, Alleppey \\
\hline $\mathbf{4 3}$ & VS 46 & YLB-7 & ARS, Thruvalla \\
\hline $\mathbf{4 4}$ & VS47 & NKRA Local & ARS, Thruvalla \\
\hline & & & tranferred to PDA \\
\hline
\end{tabular}

Yard long bean plants showing typical collar rot and web blight symptoms caused by Rhizoctonia solani were collected from the Crop Museum of College of Agriculture, Vellayani. The collar region and the leaves of infected cowpea plants showing rotting and blighting symptoms were washed with water and cut into small bits containing diseased portion along with some healthy tissue. The pieces were then surface sterilized in 0.1 per cent mercuric chloride solution for one minute followed by two to three washings in sterile water. The pieces were then transferred into sterile petri dishes containing potato dextrose agar (PDA), under aseptic condition and

incubated at room temperature. When fungal growth was visible, mycelial bits were transferred to PDA slants and labeled. The two isolates obtained from collar region and the leaf was purified by hyphal tip method and pure culture was maintained on PDA slants by serial sub culturing for further studies.

Fifteen days old seedlings were inoculated with collar rot pathogen on collar region after giving injury by pin pricking. To provide moisture a thin layer of moisture cotton was placed over inoculated region. To ensure high humidity the plants were covered with a polypropylene cover sprinkled with water to create congenial condition for pathogen. Sufficient holes were made in polythene cover for aeration. The pathogen isolated from leaf region was inoculated separately on leaves of 10 to 15 days old seedlings. For application on the leaves, the mycelial suspension of $R$. 
solani was prepared by harvesting mycelial mats and suspending in sterile distilled water (SDW). Then homogenized in warring blender for one minute and strained through a double layer muslin cloth. This was diluted with SDW in such a manner to contain 15-20 mycelial bits per microscopic field (200X). The inoculum was sprayed using a hand sprayer on the leaves. To ensure high humidity the plants were covered with a polypropylene bag sprinkled with water and having sufficient holes.

Disease incidence was calculated on the basis of percent of infected stems for collar rot. Percentage of Disease Index (PDI) of web blight was calculated as follows (Mayee and Dattar, 1986):

$$
\text { PDI }=\frac{\begin{array}{c}
\text { Number of plants affected } \\
\text { Total number of plants }
\end{array}}{\text { Number of plants assessed } \times \text { Maximum grade used }}
$$

The accessions were categorized into resistant, tolerant, moderately tolerant, susceptible and highly susceptible based on severity of the disease (Bhadrasree, 2007) as follow:

\begin{tabular}{|l|c|c|}
\hline Category & Descriptor & Severity of symptoms \\
\hline Resistant & No incidence & No symptoms \\
Tolerant & Low incidence & $<25 \%$ of plants attacked \\
Moderately tolerant & Medium incidence & $25-30 \%$ of plants attacked \\
Susceptible & High incidence & $50-70 \%$ of plants attacked \\
Highly Susceptible & Very high incidence & $>75 \%$ of plants attacked \\
\hline
\end{tabular}

\section{Results and Discussion}

A total of 44 accessions of yard long bean of diverse origin (Table 1) were sown and screened against collar rot and web blight under field conditions. Out of 44 accessions only twelve (VS 1, VS 2, VS 9, VS 14, VS 20, VS 21, VS 23, VS 24, VS 29, VS 30, VS 32 and VS 40) recorded collar rot symptoms. Among these, VS 29 showed highest incidence (26.65\%) followed by VS 30 (25\%). The rest of the accessions were free from collar rot incidence under field conditions. There was no incidence of web blight throughout growing period. These results may be due to high temperatures along with dry climate during the growing season.

Confirmation of field screening was done through artificial screening on all accessions which were used in field screening. Although, the concentration of the inoculum was constant for all genotypes during the inoculation process, the differential reaction of the accessions against $R$. solani isolate suggest variable potential of the genotypes for resistance to $R$. solani. Among 44 accessions, twelve (VS 6, VS 10, VS 13, VS 18, VS 19, VS 22, VS 32, VS 33, VS 37, VS 38, VS 39 and VS 43) were found resistant, four (VS 4, VS 35, VS 36, VS 44) were tolerant, ten (VS 5 , VS 7, VS 11, VS 14, VS 20, VS 28, VS 40, VS 41, VS 45, VS 46) were moderately tolerant, five were susceptible and thirteen were highly susceptible (Table 3). Collar rot incidence was highest in VS 21 (99.41\%) followed by VS $12(99.39 \%)$ and there was no incidence of collar rot in 12 accessions viz., VS 6 , VS 10, VS 13, VS 18, VS 19, VS 22, VS 32, VS 33, VS 37, VS 38, VS 39 and VS 43 throughout artificial screening. 
Table.3 Rating of yard long bean accessions against collar rot under artificial inoculums

\begin{tabular}{|c|c|c|c|}
\hline Category & Severity of symptoms & $\begin{array}{c}\text { No. of } \\
\text { accessions }\end{array}$ & Accessions \\
\hline Resistant & No symptoms & 12 & $\begin{array}{l}\text { VS } 6, \text { VS } 10, \text { VS } 13, \text { VS } 18, \\
\text { VS } 19, \text { VS } 22, \text { VS } 32, \text { VS } 33, \text { VS } 37, \\
\text { VS } 38, \text { VS } 39, \text { VS } 43\end{array}$ \\
\hline Tolerant & $\begin{array}{l}<25 \% \text { of plants } \\
\text { attacked }\end{array}$ & 4 & VS 4, VS 35, VS 36, VS 44 \\
\hline $\begin{array}{l}\text { Moderately } \\
\text { tolerant }\end{array}$ & $\begin{array}{l}25-30 \% \text { of plants } \\
\text { attacked }\end{array}$ & 10 & $\begin{array}{l}\text { VS } 5, \text { VS } 7, \text { VS } 11, \text { VS } 14, \text { VS } 20, \text { VS } \\
28, \text { VS } 40, \text { VS } 41, \text { VS } 45, \text { VS } 46\end{array}$ \\
\hline Susceptible & $\begin{array}{c}50-70 \% \text { of plants } \\
\text { attacked }\end{array}$ & 5 & VS 9, VS 15, VS 16, VS 24, VS 31 \\
\hline Highly Susceptible & $\begin{array}{l}>75 \% \text { of plants } \\
\text { attacked }\end{array}$ & 13 & $\begin{array}{l}\text { VS } 1, \text { VS } 2, \text { VS } 3, \text { VS } 8, \text { VS } 12, \text { VS } \\
21, \text { VS } 23 \text {, VS } 27, \text { VS } 29, \text { VS } 30, \text { VS } \\
34, \text { VS } 42, \text { VS } 47\end{array}$ \\
\hline
\end{tabular}


Table.4 Mean performance of 44 yard long bean accessions for collar rot and web blight disease under artificial conditions

\begin{tabular}{|c|c|c|c|c|c|c|}
\hline \multirow[t]{2}{*}{ Accessions } & \multicolumn{3}{|c|}{ Collar rot disease incidence after inoculation } & \multirow{2}{*}{$\begin{array}{l}\text { Length of lesion } \\
\text { of collar rot }(\mathrm{cm})\end{array}$} & \multirow{2}{*}{$\begin{array}{l}\text { Breadth of lesion } \\
\text { of collar rot }(\mathrm{cm})\end{array}$} & \multirow{2}{*}{$\begin{array}{c}\text { Web blight disease } \\
\text { index }\end{array}$} \\
\hline & I week & II week & III week & & & \\
\hline VS 1 & $75.02(59.99)$ & $75.02(59.99)$ & $99.2(85.28)$ & 2.15 & 1.35 & 34.75 \\
\hline VS 2 & $24.95(29.95)$ & $75(59.98)$ & $99.23(85.68)$ & 2.45 & 1.32 & 50.54 \\
\hline VS 3 & $25.57(30.35)$ & $75.8(60.51)$ & $98.8(84.54)$ & 1.85 & 1.23 & 41.81 \\
\hline VS 4 & $0(0)$ & $26(30.64)$ & $26(30.64)$ & 0.48 & 0.40 & 26.47 \\
\hline VS 5 & $0(0)$ & $50.84(45.46)$ & $50.84(45.46)$ & 1.38 & 0.78 & 20.98 \\
\hline VS 6 & $0(0)$ & $0(0)$ & $0(0)$ & 0.00 & 0.00 & 18.43 \\
\hline VS 7 & $0(0)$ & $51.17(45.65)$ & $51.17(45.64)$ & 0.85 & 0.70 & 20.32 \\
\hline VS 8 & $50.45(45.24)$ & $51.55(45.87)$ & $99.04(85.14)$ & 2.08 & 1.32 & 35.69 \\
\hline VS 9 & $0(0)$ & $75.40(60.24)$ & $75.40(60.24)$ & 1.58 & 1.23 & 23.96 \\
\hline VS 10 & $0(0)$ & $0(0)$ & $0(0)$ & 0.00 & 0.00 & 17.84 \\
\hline VS 11 & $0(0)$ & $25.36(30.22)$ & $50.83(45.46)$ & 0.85 & 0.58 & 26.72 \\
\hline VS 12 & $0(0)$ & $99.39(86.17)$ & $99.39(86.17)$ & 1.98 & 1.20 & 42.65 \\
\hline VS 13 & $0(0)$ & $0(0)$ & $0(0)$ & 0.00 & 0.00 & 14.33 \\
\hline VS 14 & $0(0)$ & $51.52(45.86)$ & $51.52(45.86)$ & 0.83 & 2.35 & 32.06 \\
\hline VS 15 & $0(0)$ & $75.49(60.30)$ & $75.49(60.30)$ & 1.40 & 1.13 & 32.74 \\
\hline VS 16 & $0(0)$ & $75.65(60.41)$ & $75.65(60.41)$ & 1.50 & 1.23 & 26.00 \\
\hline VS 18 & $0(0)$ & $0(0)$ & $0(0)$ & 0.00 & 0.00 & 20.36 \\
\hline VS 19 & $0(0)$ & $0(0)$ & $0(0)$ & 0.00 & 0.00 & 22.19 \\
\hline VS 20 & $0(0)$ & $26.17(30.75)$ & $50.96(45.54)$ & 0.55 & 0.25 & 31.53 \\
\hline VS 21 & $0(0)$ & $99.41(86.42)$ & $99.41(86.42)$ & 2.15 & 1.60 & 24.79 \\
\hline VS 22 & $0(0)$ & $0(0)$ & $0(0)$ & 0.00 & 0.00 & 22.25 \\
\hline VS 23 & $0(0)$ & $51.72(45.96)$ & $99.81(88.74)$ & 1.10 & 0.55 & 26.75 \\
\hline
\end{tabular}

(Data in parenthesis showing in bracket is transformed values) 
Table 4. Continued...

\begin{tabular}{|c|c|c|c|c|c|c|}
\hline \multirow[t]{2}{*}{ Accessions } & \multicolumn{3}{|c|}{ Collar rot disease incidence after inoculation } & \multirow{2}{*}{$\begin{array}{l}\text { Length of lesion } \\
\text { of collar rot } \\
(\mathrm{cm})\end{array}$} & \multirow{2}{*}{$\begin{array}{l}\text { Breadth of lesion } \\
\text { of collar rot }(\mathrm{cm})\end{array}$} & \multirow{2}{*}{$\begin{array}{l}\text { Web blight disease } \\
\text { index }\end{array}$} \\
\hline & I week & II week & III week & & & \\
\hline VS 24 & $0(0)$ & $74.31(59.52)$ & $74.31(59.52)$ & 1.70 & 0.92 & 33.96 \\
\hline VS 27 & $0(0)$ & $49.89(44.92)$ & $99.2(85.28)$ & 1.18 & 0.83 & 36.98 \\
\hline VS 28 & $0(0)$ & $25.33(30.20)$ & $50.97(45.54)$ & 0.45 & 0.23 & 23.14 \\
\hline VS 29 & $0(0)$ & $50.96(45.54)$ & $99.23(85.68)$ & 0.95 & 0.75 & 28.17 \\
\hline VS 30 & $0(0)$ & 49.67(44.79) & $98.8(84.54)$ & 1.03 & 0.65 & 24.44 \\
\hline VS 31 & $0(0)$ & $74.95(59.94)$ & $74.95(59.95)$ & 1.60 & 1.03 & 22.27 \\
\hline VS 32 & $0(0)$ & $0(0)$ & $0(0)$ & 0.00 & 0.00 & 34.76 \\
\hline VS 33 & $0(0)$ & $0(0)$ & $0(0)$ & 0.00 & 0.00 & 33.43 \\
\hline VS 34 & $24.98(29.97)$ & $99.04(85.14)$ & $99.04(85.14)$ & 2.45 & 1.40 & 44.41 \\
\hline VS 35 & $25.25(30.15)$ & $25.36(30.22)$ & $25.36(30.22)$ & 0.40 & 0.40 & 38.27 \\
\hline VS 36 & $0(0)$ & $25.09(30.04)$ & $25.09(30.04)$ & 0.30 & 0.20 & 35.47 \\
\hline VS 37 & $0(0)$ & $0(0)$ & $0(0)$ & 0.00 & 0.00 & 21.00 \\
\hline VS 38 & $0(0)$ & $0(0)$ & $0(0)$ & 0.00 & 0.00 & 17.97 \\
\hline VS 39 & $0(0)$ & $0(0)$ & $0(0)$ & 0.00 & 0.00 & 21.35 \\
\hline VS 40 & $0(0)$ & $49.36(44.61)$ & $49.36(44.62)$ & 1.05 & 0.75 & 32.74 \\
\hline VS 41 & $0(0)$ & $51.39(45.78)$ & $51.39(45.78)$ & 1.58 & 0.75 & 29.67 \\
\hline VS 42 & $0(0)$ & $98.8(84.54)$ & $98.8(84.54)$ & 2.43 & 1.63 & 46.39 \\
\hline VS 43 & $0(0)$ & $0(0)$ & $0(0)$ & 0.00 & 0.00 & 23.81 \\
\hline VS 44 & $0(0)$ & $24.76(29.83)$ & $24.76(29.83)$ & 0.58 & 0.43 & 21.97 \\
\hline VS 45 & $25.03(30.01)$ & $49.09(44.46)$ & $49.09(44.46)$ & 1.05 & 2.58 & 33.11 \\
\hline VS 46 & $0(0)$ & $51.02(45.57)$ & $51.02(45.57)$ & 1.03 & 0.78 & 27.87 \\
\hline VS 47 & $0(0)$ & $99.23(85.68)$ & $99.23(85.68)$ & 2.00 & 1.35 & 53.78 \\
\hline Mean & $5.71(4.78)$ & $42.81(37.85)$ & $51.70(45.21)$ & 0.90 & 0.75 & 31.13 \\
\hline CD $(5 \%)$ & 0.485 & 1.029 & 0.994 & 1.18 & 1.98 & 3.15 \\
\hline
\end{tabular}

(Data in parenthesis showing in bracket is transformed values) 
To find out the severity of collar rot incidence, two parameters viz., length and breadth of lesion were recorded. The length of lesion varied from $0-2.45 \mathrm{~cm}$. VS 2 and VS $34(2.45 \mathrm{~cm})$ had the highest length of lesion followed by VS $42(2.43 \mathrm{~cm})$. Lowest length of lesion was recorded by VS 36 (0.3 $\mathrm{cm})$ followed by VS $35(0.4 \mathrm{~cm})$. VS $45(2.58$ $\mathrm{cm}$ ) had the highest breadth of lesion followed by VS $14(2.35 \mathrm{~cm})$. Breadth of lesion is lowest in VS $36(0.20)$ followed by VS 28 $(0.23 \mathrm{~cm})$.

The plant disease index for web blight was highest in VS 47 (53.78) followed by VS 2 (50.54) and least in VS 13 (14.33) followed by VS 10 (17.84) (Table 4).

In this study, twelve (VS 6, VS 10, VS 13, VS 18, VS 19, VS 22, VS 32, VS 33, VS 37, VS 38, VS 39, VS 43) accessions were found as resistance to collar rot and web blight under natural field screening as well as under artificially inoculated condition. The collar rot disease severity high in young seedlings. Screening experiments by various workers have indicated highly differential response of Vigna unguiculata species to the attack of collar rot and web blight (Thies et al., 2006; Berland et al., 2009).

\section{References}

Berland, P., Thies, J. and Richard. 2009. New Sources of Resistance in Cowpea (Vigna Unguiculata) to Rhizoctonia solani. HortScience. 74: p864

Bhadrasree, S. 2007. Ecofriendly management of collar rot and web blight of cowpea. M.Sc. (Ag) thesis, Kerala Agricultural University, Thrissur, Kerala 46p.

Dubey, S. C. and Mishra, S. 1990. Studies on web blight of horse gram caused by Rhizoctonia solani. Journal of Mycology and Plant Pathology 20: 12-14.

Fery, R. L. 2002. New opportunities in Vigna. In: Janick, J., Whipkey, A. (Eds.), Trends in New Crops and New Uses. ASHS Press, Virginia, pp. 424-428.

Gupta, R. P. and Singh, R. V. 2002. Assessment of yield losses in mung bean due to Rhizoctonia solani. Journal of Mycology and Plant Pathology 32: 142.

Mayee, C. D. and Dattar, V. V. 1986. Phytopathometry. Technical Bulletin - 1, Marathwada Agricultural University, Akola. 146p.

Rachie, K. O. 1985. Introduction. In: Singh, S.R., Rachie, K.O. (Eds.), Cowpea Research, Production, and Utilization. Wiley, Chichester, pp. xxi-xxviii.

Sarutayophat, T., Nualsri, C., Santipracha, Q. and Saereeprasert, V. 2007. Characterization and genetic relatedness among 37 yard long bean and cowpea accessions based on morphological characters and RAPD analysis. Journal of Science and Technology 29: 591-600.

Sharma, J. 1999. Biological control of web blight of urd bean. Journal of Mycology and Plant Pathology 29: 101-102.

Thies, J. A., Berland, P. A. and Fery, R. L. 2006. Response of cowpea cultivars to Rhizoctonia solani in field tests. HortScience 40: p876.

\section{How to cite this article:}

Sivakumar, V., V.A. Celine and Girija, V.K. 2018. Evaluation of Yard Long Bean (Vinna unguiculata subsp. sesquipedalis) Genotypes for Collar Rot and Web Blight. Int.J.Curr.Microbiol.App.Sci. 7(07): 4238-4245. doi: https://doi.org/10.20546/ijcmas.2018.707.495 